Int. J. Morphol.,

34(2):495-497, 2016.

\title{
Pre-aortic Inter-azygos Veins: Two Case Reports
}

\author{
Venas Interácigos Pre-aórticas: Reporte de Dos Casos
}

\author{
N. S. Ntombela*; L. Lazarus* \& K. S. Satyapal*
}

NTOMBELA, N. S.; LAZARUS, L. \& SATYAPAL, K. S. Pre-aortic inter-azygos veins: Two case reports. Int. J. Morphol., 34(2):495497, 2016.

SUMMARY: This report describes two cases of multiple anomalies associated with the azygos venous system. In Case 1, the hemiazygos vein drained the $9^{\text {th }}$ to $11^{\text {th }}$ left posterior intercostal veins. At $\mathrm{T} 9$ vertebral level, the interazygos vein passed obliquely and anterior to the aorta to drain into the azygos vein on the right. In Case 2, the common venous trunk formed by the accessory hemiazygos and hemiazygos veins passed anterior to the aorta to drain into the azygos vein at $\mathrm{T} 9$ vertebral level. These findings represent pre-aortic inter-azygos veins, which is a rare variation of the azygos venous system. Pre-aortic inter-azygos veins can mimic pathologies such as enlarged lymph nodes, tumors and aneurysms leading to misinterpretation of radiographs, computerized tomography and magnetic resonance scans. Surgeons need to be aware of this type of variation so as to avoid injury of any anomalous passing venous vessels.

KEY WORDS: Anomaly; Azygos Venous system; Pre-aortic inter-azygos vein.

\section{INTRODUCTION}

The azygos venous system has a complex embryological origin, which lends to its great variability, especially on the left side (Krakowiak-Sarnowska et al., 2003). The venous system develops from the longitudinal right and left azygos lines which are embryological derivatives of the primitive postcardinal veins. The azygos line veins may also be referred to as the medial sympathetic line veins which form dorsolateral to the aorta and medial to the sympathetic chain and gradually take over the intersegmental venous drainage from the supracardinal veins (Stranding, 2008). The right azygos line develops into the vertical part of the azygos vein.

Cranially, the azygos lines join the persistent cranial ends of the postcardinal veins which form the root of the azygos on the right and together with the distal part of the anterior cardinal vein on the left, form the left superior intercostal vein (Mahato, 2009). Caudally, they join the corresponding subcardinal vein close to the inter-cardinal anastomosis thus the azygos vein originates as the ascending lumbar vein on both sides. The subcentral veins form dorsal to the aorta in the interval between the origins of the paired intersegmental arteries. These veins communicate with each other as well as the paired azygos lines and develop into the reaortic-aortic connections of the left lumbar and hemiazygos veins (Stranding). The left azygos line develops into two sets of longitudinal veins. The upper part of the azygos venous line develops into the accessory hemiazygos vein, which drains the posterior fourth to sixth or sometimes seventh intercostal spaces. The lower part of the azygos venous line, develops into the hemiazygos vein that drains the posterior lower intercostal spaces. The accessory and hemiazygos veins are usually independent systems, which connect to the azygos vein via two transverse connections at thoracic vertebral level T7 and T8 (Stranding). The classical course of the accessory and hemiazygos veins crosses posterior to the aorta, thoracic duct and oesophagus as the interazygos vein to drain into the azygos vein. Preaortic connections between the right and left components of the azygos venous system are referred to as pre-aortic interazygos veins and are described as an unusual and rare form of variation of the venous system (Nishie et al., 2009).

Large venous vessels in unusual locations following oblique courses may lead to misinterpretation of computed tomography (CT) images and accidental damage of these vessels during surgery can cause bleeding complications (Pyrzowski et al., 2007).

"Department of Clinical Anatomy, College of Health Sciences, School of Laboratory Medicine \& Medical Sciences, University of KwaZulu-Natal, Durban, South Africa. 


\section{MATERIAL AND METHOD}

The cadaveric material used in this research paper consisted of fifty fetal specimens obtained from the Discipline of Clinical Anatomy, School of Laboratory Medicine and Medical Sciences at the University of KwaZulu-Natal. Ethical clearance was granted by the Biomedical Research Ethics Committee with ethical clearance number BE043/ 010.

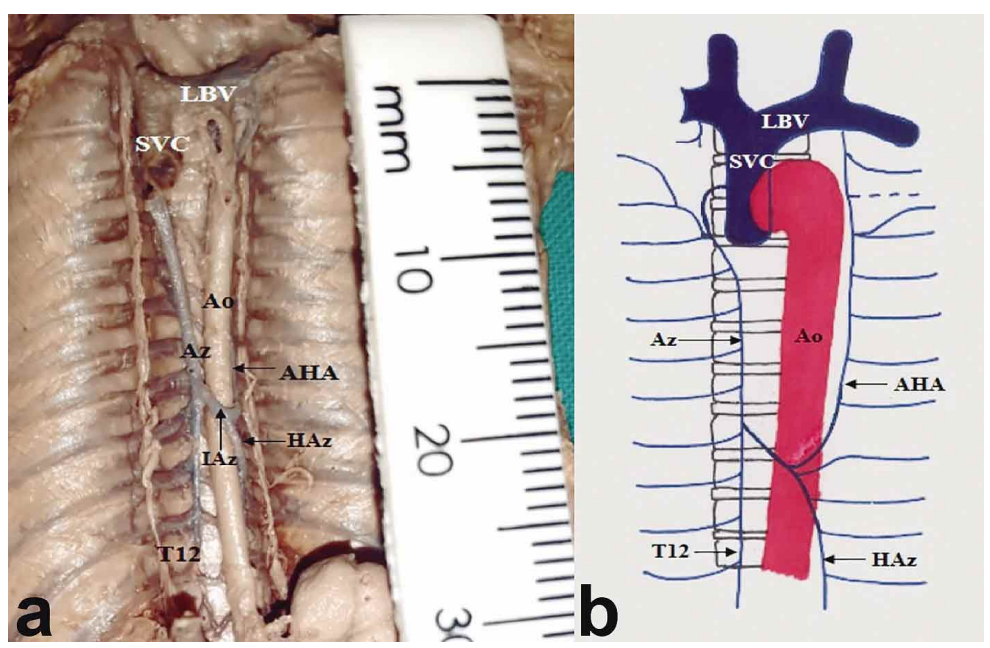

Fig. 1. a) Illustration and b) schematic showing the variation in case $1 . \mathrm{Ao}=$ Aorta; Az= Azygos vein; HAz= Hemiazygos vein; $\mathrm{IAz}=$ Interazygos vein and $\mathrm{T} 12=12$ th thoracic vertebrae.

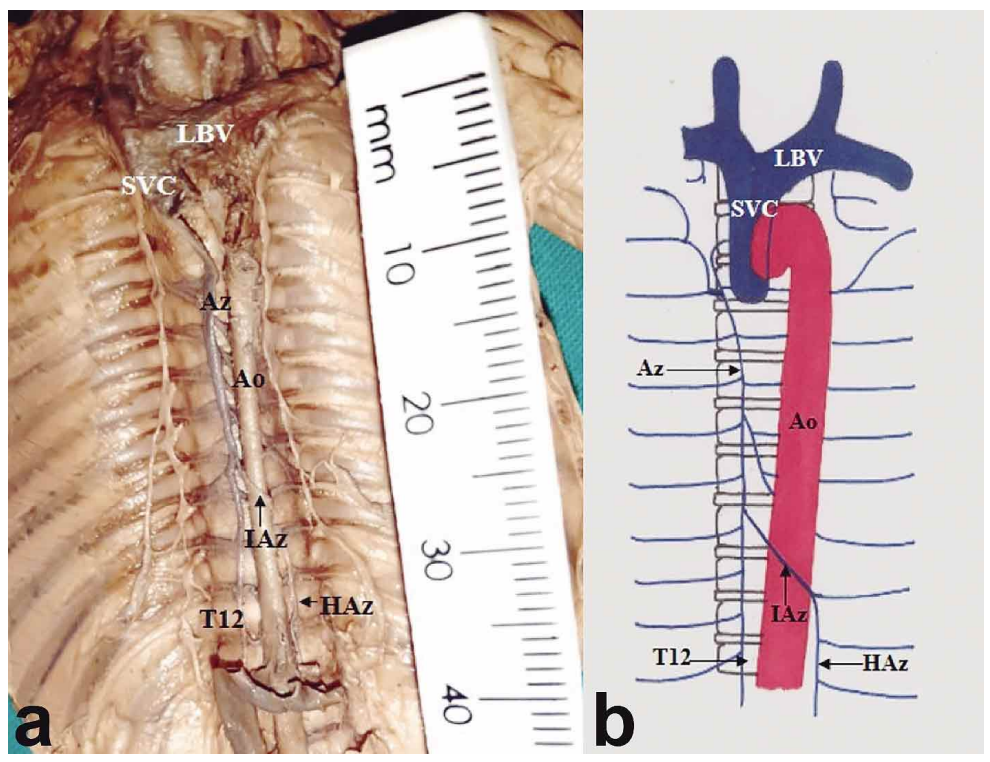

Fig. 2. a) Illustration and b) schematic showing the variation in case 2 . $\mathrm{LBV}=$ Left brachiocephalic vein; $\mathrm{SVC}=$ Superior vena cava; $\mathrm{Ao}=$ Aorta; $\mathrm{Az}=$ Azygos vein; $\mathrm{AHA}=$ Accessory hemiazygos vein; $\mathrm{HAz}=$ Hemiazygos vein and $\mathrm{IAz}=$ Interazygos vein.
The fetal specimens which consisted of 28 males and 22 females, were preserved in formalin and according to the crown rump lengths (CRL) (Moore \& Persaud, 2003), had a gestational age range of 17 to 25 weeks of intra-uterine life. Using standard anatomical dissecting techniques, the skin and the muscle attachments on the anterior rib cage were removed prior to cutting the rib cage along the mid-axillary line. The sterno-clavicular and 1st sterno-costal joints were cut and the rib cage was removed. The chest and abdominal organs were removed and the posterior thoracic wall was then exposed for further dissection under a light micro-dissecting microscope (Zeiss Stemi DV4). The patterns were sketched and photographed using a Panasonic Lumix DMC-LZ7 digital camera.

During dissection of the posterior thoracic wall, we encountered an anomaly in the azygos venous system in 2 fetal specimens. The results are depicted in Figures 1 and 2. The preaortic interazygos vein was a direct continuation of the hemiazygos vein which drained the 9 th to 11 th left posterior intercostal veins. The venous vessel passed obliquely on the anterior surface of the aorta to open into the azygos vein at T9 vertebral level (Fig. 1). In the other case, the hemiazygos vein drained the 9th to 11th left posterior intercostal veins and the accessory hemiazygos had an anomalous course, draining as far as the 1st to 8th left posterior intercostal veins. The accessory hemiazygos joined the hemiazygos vein at T10 vertebral level thus forming a common trunk with the hemiazygos vein before draining into the azygos vein. The resultant interazygos vein passed anterior to the aorta to drain into the azygos at T9 vertebral level (Fig. 2). No abnormalities in the azygos vein were observed.

\section{DISCUSSION}

Anomalies of the azygos venous system are not uncommon and are well documented in the literature. These anomalies are said to be brought about by the complex embryology from which the system develops (Mahato). It does however; appear that connections between the hemiazygos and azygos veins lying anterior to the aorta, "preaortic connections" are a rare finding. Earlier authors estimated the incidence of these connections to be present in $2.5 \%$ and $3.6 \%$ of individuals (Pyrzowski et al.). 
The interazygos veins can be formed by independent left posterior intercostal veins uniting to form a common trunk, the hemiazygos, accessory hemiazygos veins or the commonly found hemiazygos - accessory hemiazygos anastomosis (Celik et al., 1996; Gilkeson et al., 1997; Ozbek et al., 1999; Ozdemir et al., 2002). Preaortic interazygos veins can be joined by other posterior intercostal veins as in the reports by Das \& Paul (2004) and Pyrzowski et al., or accompanied by additional retroaortic anastomoses as in the report by Ozdemir et al. In our reports however, the interazygos vein in both cases was not accompanied by any pre or retroaortic vessels.

The oblique course of the interazygos vein, its unusual locality together with that of other para-aortic vessels makes it easy for radiologists to confuse these vessels with enlarged lymph nodes during imaging (Pyrzowski et al.) or para-aortic masses as in the case by Gilkeson et al.

This type of variation can possibly be explained embryologically as the persistence of an abnormal anterior communication between the left intersegmental veins and the azygos vein without involving the retroaortic subcentral veins (Das \& Paul).

Reports of the preaortic interazygos veins possibly resembling serious pathologies are well documented in the literature (Gilkeson et al.). Thus, re-emphasizing the importance of knowledge of the azygos venous system and its possible variations remains clinically significant in avoiding misdiagnosis and accidental damage of anomalous vessels resulting in hemorrhagic complications.

NTOMBELA, N. S.; LAZARUS, L. \& SATYAPAL, K. S. Venas interácigos pre-aórticas: reporte de dos casos. Int. J. Morphol., 34(2):495497, 2016.

RESUMEN: Este informe describe dos casos de múltiples anomalías asociadas con el sistema venoso ácigos. En el caso 1, la vena ácigos drena las $9^{\mathrm{a}}$ y $11^{\mathrm{a}}$ venas intercostales posteriores izquierdas. A nivel de la $9^{\mathrm{a}}$ vértebra torácica, la vena interácigos pasó oblicuamente y anterior a la aorta para drenar en la vena ácigos del lado derecho. En el caso 2, el tronco venoso común formado por las venas hemiácigos accesoria y hemiácigos pasaron anterior a la aorta para drenar en la vena ácigos a nivel de la $9^{a}$ vértebra torácica. Estos resultados representan venas interácigos pre-aórticas, que es una rara variación del sistema venoso ácigos. Las venas interácigos pre-aórticas pueden imitar patologías, como agrandamiento de nódulos linfáticos, tumores y aneurismas que conducen a una mala interpretación de las exploraciones por radiografías, tomografía computarizada y resonancia magnética. Los cirujanos deben ser conscientes de estos tipos de variaciones para evitar lesionarlos.

PALABRAS CLAVE: Anomalía; Sistema venoso ácigos; Venas interácigos pre-aórticas.

\section{REFERENCES}

Celik, H. H.; Sargon, M. F.; Aldur, M. M. \& Cumhur, M. An anomalous course of the interazygos vein. Surg. Radiol. Anat., 18(1):61-2, 1996.

Das, S. \& Paul, S. Preaortic interazygos vein: a case report. Braz. J. Morphol. Sci., 21:141-3, 2004.

Gilkeson, R. C.; Goodman, P. C. \& McAdams, H. P. Anomalous azygous-hemiazygous anastomosis: radiographic findings. AJR Am. J. Roentgenol., 168(1):285-6, 1997.

Krakowiak-Sarnowska, E.; Wisniewski, M.; Szpinda, M. \& Krakowiak, H. Variability of the azygos vein system in human foetuses. Folia Morphol. (Warsz.), 62(4):427-30, 2003.

Mahato, N. K. Anomalous accessory hemiazygos system with persistent cranial segment of posterior cardinal vein - A case report. Braz. J. Morphol., 26:177-9, 2009.

Moore, K. L. \& Persaud, T. V. N. The Developing Human. Clinically Oriented Embryology. $7^{\text {th }}$ ed. Philadelphia, Saunders, 2003. pp.331-3.

Nishie, A.; Barloon, T. \& Schreiber, A. Preaortic interazygous vein; mimicker of other pathologies. Clin. Imaging, 33(2):144-5, 2009.
Ozbek, A.; Dalçik, C.; Colak, T. \& Dalçik, H. Multiple variations of the azygos venous system. Surg. Radiol. Anat., 21(1):83-85, 1999.

Ozdemir, B.; Aldur, M. M. \& Celik, H. H. Multiple variations in the azygos venous system: a preaortic interazygos vein and the absence of hemiazygos vein. Surg. Radiol. Anat., 24(1):68-70, 2002.

Pyrzowski, J.; Spodnik, J. H.; Lewicka, A.; Popawska, A. \& Wójcik, S. A case of multiple abnormalities of the azygos venous system: a praeaortic interazygos vein. Folia Morphol. (Warsz.), 66(4):353$5,2007$.

Stranding, S. Gray`s Anatomy. The Anatomical Basis of Clinical Practice. $40^{\text {th }}$ ed. Philadelphia, Elsevier, 2008. pp.207-8, 939-40.

\section{Correspondence to:}

Professor K.S. Satyapal

Department of Clinical Anatomy

College of Health Sciences

School of Laboratory Medicine \& Medical Sciences

University of KwaZulu-Natal

Private Bag X54001

Durban, 4001

SOUTH AFRICA

Received: 07-10-2015

Email:satyapalk@ukzn.ac.za
Accepted: 13-04-2016 